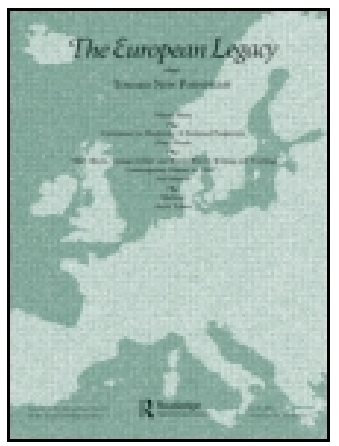

The European Legacy

Toward New Paradigms

ISSN: 1084-8770 (Print) 1470-1316 (Online) Journal homepage: http://www.tandfonline.com/loi/cele20

\title{
The Fundamental Contradiction of Modern Cosmopolitanism
}

James Alexander

To cite this article: James Alexander (2016) The Fundamental Contradiction of Modern Cosmopolitanism, The European Legacy, 21:2, 168-183, DOI: 10.1080/10848770.2015.1126479

To link to this article: https://doi.org/10.1080/10848770.2015.1126479

曲 Published online: 20 Jan 2016.

Submit your article to this journal $๘$

Џll Article views: 266

Q View related articles $\sqsubset$

View Crossmark data $[7$ 


\title{
The Fundamental Contradiction of Modern Cosmopolitanism
}

\author{
James Alexander \\ Department of Political Science, Bilkent University, Bilkent, Ankara 06800, Turkey
}

\begin{abstract}
This article is a study of that eminently European contribution to world politics: the idea of cosmopolitanism. The argument is that modern cosmopolitanism depends on two postulates which are contradictory. Cosmopolitans have always claimed, "There are two cities, one higher and one lower." Modern cosmopolitans, however, claim, without abandoning the first postulate, "There is only one city." In this article I ask four questions which enable the contradiction between these to be illustrated. These are: Is the cosmopolis the higher of two cities? Is it a community of men and gods? What is the criterion of inclusion in it? How free is one to be cosmopolitan? Along the way I clarify what I consider the fundamental contradiction of modern cosmopolitanism to be by distinguishing it from what I call the fundamental problem and the fundamental paradox of cosmopolitanism.
\end{abstract}

Modern cosmopolitanism is the distinctively European contribution to a vision of an entire world politics. Unfortunately, it is now in a state of contradiction. The contradiction is fundamental, that is, philosophical, yet I think it is only brought to our attention if we turn to the history of thought, because it is only in considering older forms of cosmopolitanism that we see where the contradiction lies. Costas Douzinas has suggested that the historical study of the "metaphysics of cosmopolitanism" can be used to indicate some of the philosophical defects of modern cosmopolitanism. ${ }^{1}$ In this article I want to identify the original postulate of cosmopolitan theories, to show that this postulate is retained by modern cosmopolitan theories, and to argue that it is contradicted by the further postulate which makes modern cosmopolitanism distinctively modern.

By referring to "modern cosmopolitanism" I am not claiming that there is a single coherent movement of cosmopolitanism. Cosmopolitans operate at many different levels, and of course at all levels disagree in many respects. What I am attempting to do here is to explain what is behind such disagreement. The claim is that all modern cosmopolitans depend on certain assumptions. I shall call these assumptions "postulates" since it is part of my purpose to emphasize the responsibility cosmopolitans should take for them. There are two such postulates, and, as I hope to show, they are contradictory. But since one postulate is what makes modern cosmopolitanism cosmopolitan, and the other is what makes modern 
cosmopolitanism modern, both postulates seem to be necessary. These are, to anticipate, "There are two cities" and "There is one city." Modern cosmopolitan theories are, I argue, in a state of contradiction because the cosmopolitan order they discuss is both a higher city to be somehow distinguished from a lower city, and the only the city there is.

Before I begin, a word about the literature on the subject. Modern cosmopolitans have responded to this contradiction in one of three ways. Either they have ignored the contradiction by emphasizing the particular forms taken by cosmopolitanism over any universal vision of cosmopolitan order. This is quite rare amongst theorists, though it is standard now in empirical studies. ${ }^{2}$ Or they have ignored it by proposing a one-sided theory of the universal over the particular. This, as we shall see, is the traditional way of responding to the contradiction. But the more distinctively modern response is to conceal the contradiction by offering a theory in the form of a compromise between the universal and the particular. The many recent adjectival cosmopolitanisms which have proliferated- "layered," "balanced," "embedded," "moderate" and so on ${ }^{3}$-are theories in the form of a compromise, as are those which appeal to "imagination" or "hope" rather than to an "ideal,"4 and those which are justified by "the experience and conviction of many people" rather than by argument. ${ }^{5}$ Such theories are troubled by the problem of how to relate the empirical manifestations of the cosmopolitanism we see in the world to some sort of normative principle. ${ }^{6}$ We may well agree with Charles Beitz's view that "in the application of principles to practice, normative and empirical considerations interact in complex ways." ${ }^{7}$ But this is to understate to case. Complexities may be so great as to be beyond coherent argument. Michael Oakeshott once declared that it is unclear "whether any theory can be satisfactory which is a compromise." What I want to argue here is that a satisfactory modern theory of cosmopolitanism cannot be a theory in the form of a compromise. It must instead be a theory in the form of a recognition of the contradiction which exists behind the compromise.

A characterization of modern cosmopolitanism in terms of a contradiction is, of course, also to some extent an argument against it. Most of the recent literature on cosmopolitanism, however, has not only sought to characterize cosmopolitanism in some way or other but also to offer arguments for it. ${ }^{9}$ This implies that even when the cosmopolitan literature considers the difficulties facing cosmopolitanism it is prevented by its commitment to cosmopolitanism from considering any of those difficulties to be fundamental. In the nineteenth century W. E. H. Lecky rightly said that "the speculative opinions which are embraced by any large body of men are accepted not on account of the arguments upon which they rest, but on account of a predisposition to receive them." ${ }^{10}$ Few modern cosmopolitans are likely to be convinced by an argument against cosmopolitanism. But if they can be persuaded to consider my characterization of it in terms of a contradiction, they might at least consider the possibility that the difficulties faced by modern cosmopolitanism are fundamental.

In order to make the argument fully clear, I shall begin with a short history of cosmopolitanism, before I go on to ask four related questions about both the older forms and the modern forms of cosmopolitanism. These are: Is the cosmopolis the higher of two cities? Is it a community of men and gods? What is the criterion of inclusion in it? How free is one to be cosmopolitan? Along the way I will clarify what I consider the fundamental contradiction to be by distinguishing it from what I call the fundamental problem and the fundamental paradox of cosmopolitanism. 


\section{A Short History of Cosmopolitanism}

The history of cosmopolitanism is usually seen as something highly discontinuous. In this history there are first the Stoics, then a hiatus until Kant, after which we have the revival of cosmopolitan thought in the late twentieth century. Garrett Brown suggests that cosmopolitanism disappeared between AD 185 and 1480. ${ }^{11}$ In a similar way, Ulrich Beck singles out three "moments," which he associates with the Stoics, Kant, and Arendt and Jaspers. ${ }^{12}$ Often such histories are simply concerned with setting up a loose frame for discussing modern problems, such as crimes against humanity, the plight of political refugees or global poverty. ${ }^{13}$ I think instead that the history of cosmopolitanism should be seen as a history in three stages, each of which is conditioned by metaphysical beliefs (or by lack of them), particularly by the beliefs (or lack of them) about God or the gods. It follows that this has to be an exercise at least in part in the history of political theology. Even the better recent histories of cosmopolitan thought have tended to secularize its history so that modern cosmopolitanism has only a highly discontinuous relation to older cosmopolitanism. ${ }^{14}$ One has to go to earlier writers to find a full recognition of the religious strand in cosmopolitanism. ${ }^{15}$ To my mind, the best way of seeing the entire history of cosmopolitan thought is the one sketched by Ernest Barker:

Aristotle would have preserved the distinction between Greeks and barbarians, dealing with the former as a leader or hegemon, and with the latter as a master or despotes. Alexander did the opposite. He preferred to act in the spirit of the policy afterwards enunciated by Eratosthenes (an Alexandrian scholar of the next century) who, "refusing to agree with men who divided mankind into Greeks and barbarians and advised Alexander to treat the former as foes and the latter as friends, declared that it was better to divide men simply into the good and bad." ... This meant a great revolution. It meant the appearance of the cosmopolis in place and instead of the polis. It meant the appearance of the idea of the equality of all men-urban or rural, Greek or barbarian-in that cosmopolis.... This conception of the cosmopolis, and the cognate conception of the equality and fraternity of all men within its general embrace, are the fundamental conceptions which inaugurate a new epoch-an epoch which succeeds to that of the polis, as it precedes that of the national state; an epoch which covers the eighteen centuries (300 B.C.-A.D. 1500) between Aristotle and Alexander at one end and Luther and Machiavelli at the other. ${ }^{16}$

Barker's history is far more continuous because he does not attempt to separate philosophy and religion. If Barker is right, the great era of cosmopolitanism was the era in which men distinguished a higher city from a lower city, civitas Dei from civitas terrena. This certainly puts modern cosmopolitanism in perspective, for it indicates that some sort of vision of all humanity forming one city has existed for a long time, and has had a much more continuous history in religion than it has in philosophy or politics. Broadly, one could say that the earliest cosmopolitans, the Cynics and Stoics, were polytheistic (although this is ambiguous: some Stoics appealed to a fairly monotheistic "God of the philosophers" in much the same way as Aristotle had done), and these were followed in the West by Christians, who were monotheistic. When Christianity was withdrawn from Western political thought-which cannot be said to have occurred in a "moment" but in stages between the sixteenth and twentieth centuries - the cosmopolitanism which emerged was something which is rarely called, but nonetheless is, a secular cosmopolitanism.

Though modern cosmopolitanism was glimpsed before the Enlightenment, there is no question that the Enlightenment was the great era of the revival of the cosmopolitan ideal, though it was not until the past thirty years or so that all the theoretical issues surrounding 
a modern assertion of cosmopolitanism became a matter of considerable debate, especially among academics. When seen in this way, modern cosmopolitanism seems to have emerged as a political revision of what was originally a philosophical or religious vision. It was conditioned by the decline of theological politics and the rise of a secular politics which though it was much exercised by the new concept of the state and related concepts such as nation, representation, parties and so on, was always in part susceptible to secular and enlightened versions of the old religious or philosophical ideals. These ideals-equality, law, justice-always suggested that a universality of application was at least theoretically possible, and when the theoretical possibility was aligned with a practical possibility, there emerged the modern concept of cosmopolitanism.

It is with this in mind that we have to ask four questions about how modern cosmopolitanism compares to its antecedents.

\section{Is the Cosmopolis the Higher of Two Cities?}

Until the eighteenth century all cosmopolitans distinguished two cities, and considered the higher city to be the one which concerned them. The higher city was universal; the lower city was particular, that is, composed of many cities. The higher city was ideal; the lower city was actual. The first reputed cosmopolitan, Diogenes the Cynic, when asked which city he was from, said: "I am a citizen of the world (Kosmopolités)." Scholars still wonder what he meant by this. We do not know whether he had a theory of the higher city: all we can be certain of is that he was gesturing away from the lower city. Perhaps he meant only that he was "a homeless exile, to his country dead, a wanderer who begs his daily bread"-apolis, without a city, aoikos, without a home. ${ }^{17}$ But even in this case he was using political language in a wholly original way. We could say that he "depoliticized" political language. ${ }^{18}$ But we could also say that he politicized philosophical or religious language. This blurring of language was what made possible the development of theories of cosmopolitics alongside the standard theories of politics. From that time on, to paraphrase Hobbes (who disliked the phenomenon, and clearly wanted to bring the era of cosmopolis to an end), everyone who thought about politics saw double. ${ }^{19}$

Cosmopolitanism was always dualistic. Jens Bartelson quotes Seneca to this effect: "Let us embrace with our minds, two commonwealths: one great and truly common... the other one to which the particular circumstances of birth have assigned us... which pertains not to all men but a particular group of them." ${ }^{20}$ In the Old Testament it was prophesied that the God of Heaven would set up a kingdom which would never be destroyed but would destroy all other kingdoms (Dan. 2.44). Sometimes the kingdom, or city, was seen as eschatological, coming at the end of time (as Hobbes saw it in Leviathan), but in Christianity it was a higher city, a city of God, which was in a sense present here and now. There were ambiguities about the status of this city or kingdom in the New Testament. On the one hand it was said: "The kingdom of God is within you" (Luke 17.21), and on the other: "For here have we no continuing city, but we seek one to come" (Heb. 13.14). But, either way, there was a continual distinction of the kingdom of this earth and the kingdom not of this earth. Paul distinguished "Jerusalem which is above" from "Jerusalem which now is" (Gal. 4.25-26). The "New Jerusalem" was a higher city that would come out of Heaven "as a bride adorned for her husband" (Rev. 21.2). Augustine later formalized the dualism when he distinguished the two cities, the city of God and the city of earth. Both the Roman Empire and Roman 
Church were to complicate cosmopolitan with imperial ideas, but it is possible to say that until the sixteenth century cosmopolitanism was a decisive element in political thought, and until that point it was always dualistic.

It would not be correct to say, on the other hand, that modern cosmopolitanism is monistic. But since the eighteenth century most cosmopolitans have claimed that there is only one city. This means that what was formerly considered to be the lower city is now considered to be the only city, even though in some sense also what was formerly considered to be the higher city. This is the starting point of all modern versions of cosmopolitanism. So, for instance, we have recently been told that we become cosmopolitan "by regarding the coexistence of human beings as one (whether or not ideal) community." ${ }^{21} \mathrm{Or}$ that cosmopolitanism "resides in social mechanisms and dynamics"; that it is "the reality of contemporary society"; that it is "already embedded in rule systems and institutions." 22 No modern cosmopolitan ever distinguishes two cities as earlier cosmopolitans did. Even when mention is made of a cosmopolitan ideal, it "does not refer to a transcendental ideal, but [an ideal which] is immanent to the material conditions of global interdependence." 23

This does not mean, however, that modern cosmopolitans are monistic. They are ambivalent. They seek a monism they cannot have, while adopting a dualism they do not believe in. Kant is often taken to be the founder of modern academic cosmopolitanism. He considered cosmopolitanism solely in terms of law, as one of the spheres of law. ${ }^{24}$ Many modern cosmopolitans complain that Kant only took cosmopolitanism as far as "universal hospitality"-rather than further into universal justice. ${ }^{25}$ But Kant's theory was highly ambivalent about the status of a cosmopolitan order. Just as Christians spoke of the "Kingdom of God," he spoke of the "Kingdom of Ends." If we were to act according to the categorical imperative, Kant argued, this would be to belong to a "systematic union of different rational beings through common laws." ${ }^{26}$ Scholars still cannot agree on whether the Kingdom of Ends was metaphysical, in which case it was a secularization and minimization of older Stoic or Christian ethical ideals, and of ideal significance only, ${ }^{27}$ or political, in which case, as Kant saw, the unanswerable question of how it was to be established was raised and was probably to be answered "By force." 28 There are subtleties in Kant which are beyond my brief discussion, but the fact that scholars interpret him so differently is an indication that even the founding statement of modern cosmopolitanism is troubled by the contradiction.

Any study of modern cosmopolitan literature reveals that its major problem is how to overcome the dualism which was explicit in older cosmopolitanism and which survives to complicate the monism now sought for. Not everyone recognizes the problem. Some do, but even when they do, they tend to assume that some sort of compromise, or affirmation of hope, is sufficient to overcome the problem of whether the city of cosmopolitans is the only city or one city of two. ${ }^{29}$ Others appear to solve the problem by saying that cosmopolitanism is a word both for an object of study and for the study itself. Ulrich Beck does not want any theory of cosmopolitanism to resemble the "banal" or "latent" cosmopolitanism found in society, so he suggests that cosmopolitanism is, in academic thinking, an "empirical hypothesis." 30 Robert Fine in a similar way treats cosmopolitanism as if it is identical to "cosmopolitan social theory." ${ }^{11}$ David Held even declares: "Realism is dead; long live cosmopolitanism." 32 About this we may well ask: if cosmopolitanism is embedded in reality, can it really subjectively be considered a means by which cosmopolitanism in its objectivity is brought to consciousness? Is cosmopolitanism a political fact, a political ideal, an academic hypothesis about facts, or an academic theory about ideals? The answer, dismayingly, seems to be "All of these." 
No wonder we find Beck suggesting that "a cosmopolitan society means a cosmopolitan society and its enemies." ${ }^{33}$ But what this means is that modern cosmopolitanism is neither an inclusive unity nor an exclusive partiality. It is both. Yet this is a contradiction. Before I go on to explain why the contradiction exists, it is important to distinguish between what I call the fundamental contradiction of modern cosmopolitanism from what I call its fundamental problem and its fundamental paradox.

\section{The Fundamental Problem, Fundamental Paradox, and Fundamental Contradiction of Cosmopolitanism}

We have to distinguish the fundamental problem of modern cosmopolitanism from its fundamental paradox, and both of these from what I am particularly concerned with here, its fundamental contradiction. The fundamental problem, as Bartelson puts it, is that we are "torn between what appears to be the conflicting demands of cosmopolitan and communitarian moral vocabularies." The fundamental paradox is different. It is-and I quote Bartelson again - that "every effort to impose a given set of values on the existing plurality of communities in the name of a common humanity is likely to be met with resistance on the grounds of its own very particularity." ${ }^{34}$ In other words, that the cosmopolitan moral vocabulary might be no more than one communitarian moral vocabulary imperially extended over all others. The fundamental contradiction differs from both of these, though it is related to them. It is that the major postulate of modern cosmopolitanism (that there is one city) contradicts the major postulate of ancient cosmopolitanism (that there are two cities).

Let me illustrate the contradiction with an image. Originally cosmopolitanism was an explicit duality: there was this city, as distinguished from another, higher city; however, if one had the right credentials one was a member of the higher city, now, even in this lower city, so that one was a member of both cities at once. Imagine two parallel lines: railway tracks perhaps. If I am only a member of the lower city, a communitarian, then I run on one track only, but if I am also a member of the higher city, and therefore a cosmopolitan, then I run on two tracks. As Hobbes says, I see double. This is the image for cosmopolitanism before the eighteenth century. Modern cosmopolitanism involves a wholly different image. It rejects the view that there are two lines, with one accessible only to cosmopolitans, and the other accessible to everyone else. Modern cosmopolitans run on only one track, yet it is a track with two ends-one end is in the present, the actual, and the other end in an indefinite future but nonetheless a future which is measured by the ideals we hold now. Perhaps we expect those ideals to be achieved in the future, perhaps we expect them to fail in the future. In short, we see ourselves dynamically, not statically: we see ourselves in terms of possible progress in history.

The particular problem is that modern cosmopolitanism has to be represented in terms of an image of two parallel lines, and an image of one line running from one point to another at one and the same time. The modern cosmopolitan thus has his philosophical or theological cake, and then tries to eat it politically. If we ask a cosmopolitan whether his or her ideal is an "immediate disjunctive transcendent parallel possibility" or an "indefinite immanent realisable future ideal," the honest answer should be "Both." It is this ambiguity which makes all modern cosmopolitan literature practically possible-but also, strictly, impossible.

The fundamental problem has existed for as long as there has been any sort of cosmopolitanism or any sort of universalism. It is the paradox and the contradiction which are 
novel. The paradox implies that any universal vision may be particular. This only became a problem after the Enlightenment. No one before then would have been concerned by the fact that a universal was a particular. They would have said: "Of course, it is necessary to believe this rather than that to belong to the universal community." But after the Enlightenment the modern cosmopolitan wanted to make the universal the sum of particulars. This should be considered a perfect example of an "empty signifier." The fundamental contradiction implies that modern cosmopolitanism seeks something impossible exactly because it seeks a universal which is both particular and which is not particular because it includes all particulars.

The modern cosmopolitan may not be aware of this contradiction, but he or she is very likely to be aware of the paradox, and is almost inevitably aware of the problem. To repeat:

(1) The problem is that I aspire to the universal, but I am torn between the universal and the particular.

(2) The paradox is that I am torn between the universal and the particular, but the universal itself may be a particular.

(3) The contradiction is that I want both the universal and the particular, where the universal is at one and the same time both a particular, and thus separate from other particulars, which it excludes, and the set of particulars, and thus includes all particulars within itself.

\section{Is the Cosmopolis a Community of Men and Gods?}

The contradiction exists because modern cosmopolitanism is atheistic. Stoics and Christians associated the higher city with the gods or God. But modern cosmopolitans, in eschewing any sort of transcendental metaphysics, whether philosophical or theological, have declared that cosmopolitans can only concern themselves with anthropological facts and ethical possibilities. ${ }^{35}$ So the cosmopolitan order is only a city of humans.

All older cosmopolitans knew that their cosmopolitan order was not of this world because it was where humans lived with God or the gods. Diogenes is said to have used a famous argument:

All things belong to the gods. The gods are friends to the wise, and friends share all property in common; therefore all things are the property of the wise... The only true commonwealth [politeia] was, he said, that which is as wide as the universe $[\text { kosmos }]^{36}$

This argument was a staple of Stoic thought from Zeno to Marcus Aurelius. In the previous section I quoted Bartelson quoting Seneca. But Bartelson did not quote him in full. Seneca actually said that there are two commonwealths, the first of which is the "one great and truly common - in which gods and men are contained." ${ }^{37}$ In the same way, and even more emphatically, Christians divided the world into two parts, one divine, one human. When Jesus said "Render... unto Caesar the things that are Caesar's; and unto God the things that are God's" (Matt. 22.21), he distinguished two cities, one Caesar's and one God's. And, famously, when Pilate asked him whether he was the King of the Jews, he said, "My kingdom is not of this world [kosmos]" (John 18.36). In both Stoicism and Christianity, despite obvious differences, there was the sense that by becoming cosmopolitan one became the same as the gods, through apotheosis, or one was taken into God, through theosis. 
Now, the modern cosmopolitan might say that this is all irrelevant. Since the sixteenth century politics has been secularized. In a brilliant summary, Lecky wrote that this occurred in two steps which he called "the triumph of toleration and the triumph of civil liberty." Both "represented a movement of secularization: for by the first theological questions were withdrawn from the sphere of politics, and by the second the principle of authority was removed from a theological to a secular basis." ${ }^{38}$ If things were this simple, there would be nothing more to be said. But it is possible to doubt whether secularization is complete. Perhaps what remains from older theories has a dialectical relation to those older theories. Carl Schmitt famously declared: "All significant concepts of the modern theory of the state are secularized theological concepts not only because of their historical development... but also because of their systematic structure." ${ }^{39}$ If this is so, then schemes such as the one Jonathan Israel has outlined that distinguishes between the "radical enlightenment" (based on reason), the "moderate enlightenment" (based on reason as well as faith and tradition), and presumably a third unenlightened position (based on faith and tradition), are too simple. ${ }^{40}$ They ignore the fact that even enlightened ideas may well have a dialectical relation to older religious or philosophical ideas.

The problem is how we are to make sense of religion in the history of political thought in the last five centuries or so. A tentative suggestion has been made by David Boucher who suggests that the decline of religion in politics should not be understood in terms of a simple secularization hypothesis; rather, he suggests, at least from the eighteenth century, theories which formerly existed alongside each other-in parallel, so that men saw double-are now taken to be elements which must be reconciled in one theory. ${ }^{41} \mathrm{He}$ points out that most political theories before the eighteenth century were framed in terms either of a "universal moral order" or of "empirical realism," with, say, Plato, Aristotle, Aquinas, Kant on one side, and Thucydides, Machiavelli, and Hobbes on the other. Clearly, in terms of this distinction, cosmopolitans were always theorists of a universal moral order. Boucher's claim is that since the eighteenth century, most political theorists have looked for a reflexive, dialectical or historical theory which might effect a reconciliation between a universal moral order and empirical realism and therefore between theory and practice, between the higher and the lower city. This is an interesting claim. It is a rare theorist, nowadays, who takes his stand on pure ideals, or on a bare statement of facts. What follows from this is that the modern cosmopolitan, unlike older cosmopolitans, is not a simple advocate of a "universal moral order" but an advocate of reconciliation.

It seems that we are in an interestingly sub-Hegelian age. Seeking resolution or reconciliation, either we sense that we cannot find it and fall back on a one-sided view (which emphasizes a universal moral order over empirical realism, or vice versa), or we continue to hope that we can find it and consider all sorts of compromises as candidates for the reconciliation we hope to find. This is, I think, why John Rawls's phrase "reflective equilibrium" is so popular amongst political theorists nowadays. It is a phrase intended to suggest that what is sought is not a pure ideal or a pure statement of facts but something which can trade in both theory and practice.

Cosmopolitanism should be understood as a theory of politics which, like so much else, has gone through a Feuerbachian reversal. Everyone is familiar with Marx's utterance: "Man makes religion, religion does not make man," which is typical of this sort of reversal. ${ }^{42}$ The modern cosmopolitan is Feuerbachian in that he agrees that the gods are the ideals of men projected onto the heavens, and now supposes that, since we know this, we have a duty 
to bring our ideals back to earth. The problem is that the modern cosmopolitan has great difficulty in establishing exactly what cosmopolitanism is, now that it has been brought back to earth. If the cosmopolitan order is only of this world, then there is a difficulty, since it is far from obvious that a cosmopolitan order can only be of this world. Or if it can, then this must be because the criterion of inclusion is simply that one is human and not this or that sort of human. Which leads us to the question of the criterion of inclusion.

\section{What is the Criterion of Inclusion in a Cosmopolitan Order?}

It is difficult to say what the criterion of inclusion in a modern cosmopolitan order is. The contrast with older forms of cosmopolitanism should be evident. For the Stoics, the criterion was reason, so those included in the higher city were philosophers or wise men. Cicero argued:

Since there is nothing better than reason, and since it exists both in man and god, the first common possession of man and God is reason. But those who have reason in common must also have right reason in common. And since right reason is Law, we must believe that men have Law also in common with the gods. Further, those who share the Law must also share Justice; and those who share these are to be regarded as members of the same commonwealth [civitas]. ${ }^{43}$

For Christians the criterion of inclusion was not reason but faith: not the wise but the faithful belonged to the higher city. This of course involved a revolution, since faith had a highly angular relation to reason, and could even be opposed to it.

Hath not God [wrote Paul] made foolish the wisdom of the world? For seeing that in the wisdom of God the world through its wisdom knew not God, it was God's good pleasure through the foolishness of the preaching to save them that believe. Seeing that Jews ask for signs, and Greeks seek after wisdom: but we preach Christ crucified, unto the Jews a stumbling-block, and unto Gentiles foolishness; ... God chose the foolish things of the world, that he might put to shame the wise. (1 Cor. 1.20-27)

There is an obvious structural difference between reason and faith. According to the Stoics man shares reason with the gods (in a way that was rarely, if ever, specified), while according to the Christians man owes faith to God (in a way that was specified, though it had its own obscurities). Augustine in The City of God no longer theorized civitas in terms of reason, justice and law but in terms of love: "Two cities... have been created by two loves." 44 There was a higher love, the love of God (and therefore the love of neighbor), and the love of self. Ought did not, in this case, imply can. For the higher love was commanded even though it was impossible. Hence Christ's crucifixion, which was God's concession to save a humanity incapable of saving itself through its reason. Yet in Christianity, there was, as in Stoicism, two worlds, or two cities: the first in which men were with God (in the "kingdom of God" or the "New Jerusalem," which was on earth and was anticipated or embodied by the ekklesia: "church" or "community"), and the second in which all men lived.

Modern cosmopolitanism, by contrast, is atheistic, anthropological rather than theological, and in lacking gods or God has no way of distinguishing the higher city, which is not of this world, from the lower city, which is of this world. The two cities are, as a consequence the same: and yet they are not. This makes it extremely difficult, if not impossible, to say what the criterion of inclusion is. Bartelson rightly observes that most older forms of cosmopolitanism depended on some sort of "cosmological belief." But since by his own account most cosmopolitan theorists after the eighteenth century attempted to ground cosmopolitanism 
on some sort of anthropological fact such as "sociability," it is rather odd that his book ends with the suggestion that we should reformulate "our conceptions of community in the light of our cosmological beliefs about the human habitat." 45 The problem is that if we are to depend on anthropological facts, cosmopolitanism will be completely inclusive-it will include all humans - whereas if we are to depend on cosmological beliefs, cosmopolitanism will be exclusive-it will include only those humans who have those beliefs.

In the last three centuries there have been three ways of answering the question "What is the criterion of inclusion in a cosmopolitan order?"

(1) Some cosmopolitans have begun with a universal principle of inclusion, though this is arguably arbitrary, ignores reality, and is necessarily a principle of exclusion as well as inclusion; ${ }^{46}$

(2) Some have begun with empirical reality, that is, hybridity, plurality, marginality and so on, though this makes it impossible to define cosmopolitanism, since cosmopolitanism is everything and anything it is said to be; ${ }^{47}$

(3) Some have begun neither with empirical reality nor normative principles but instead have sketched some sort of "reflective equilibrium" between them, though this seems to involve the reconciliation of two positions that are theoretically irreconcilable. ${ }^{48}$

Each position has advantages and disadvantages. If one has a criterion, one has an exclusive cosmopolitanism; if one lacks a criterion, one achieves inclusivity at the cost of a clear sense of why that inclusivity is cosmopolitan; if one attempts a compromise between these two positions one is involved in contradiction.

Every cosmopolitan theorist is thus exercised by the same problem whether to begin with universality, particularity, or both. It has to be said that universality has gone out of fashion since the end of the last century. Toni Erskine, for instance, wants an "embedded cosmopolitanism" in which the priority is to "maintain the integrity of a particularist moral starting point." 49 David Held declares that while his theory "aims at being universal, it tries to address cultural and political specificity seriously." It does this in the form of a compromise which he calls a "layered cosmopolitanism"-a "mix of regulative principles and interpretive activity." ${ }^{50} \mathrm{He}$ proposes a set of "metaprinciples," "principles" and "policies" which involves the imposition of the universal on the particular while also denying that the universal is being imposed on the particular. ${ }^{51}$ The contradiction is evident in the following passage:

[Cosmopolitanism] builds on principles that all could reasonably assent to. ... On the other hand, the cosmopolitan point of view must also recognize that the meaning of these cannot be specified once and for all. That is to say, the connotation of these basic ideas cannot be separated from the hermeneutic complexity of traditions. ${ }^{52}$

By contrast, David Harvey is critical of Held and other "New Cosmopolitans"-Martha Nussbaum, Ulrich Beck, Kwame Anthony Appiah and others-who advocate an "ethereal and abstracted universalism" while making concessions to particularity, which is incompatible with such universalism. He observes correctly that Held's "caveat [about particularity] has immense implications" for his universalism, since it means that every universal principle can be interpreted "any which way." He sees that most cosmopolitan theorists want to overcome and yet cannot overcome the contradiction of the universal and the particular. He claims, probably rightly, that the particular is usually "opportunistically appealed to [by such theorists] in order to discredit unfavored or promote favored universal positions." This 
is all exemplary. But when he turns to his own theory we find, again, the same problem we saw in Erskine. Against Held's contradictory "layered cosmopolitanism," Harvey advocates a more pluralistic vision of "subaltern cosmopolitanisms." He tells us that the "cosmopolitan project" needs "a dialectic, process-based, and interactive approach to world historical geography." 53 All we can suppose this to mean is that cosmopolitanism is whatever anyone says it is, in which case it is not clear why cosmopolitanism is cosmopolitan as such. It lacks a principle of inclusion.

The problem, to summarize, is whether all humans are included within the cosmopolitan order, or only those humans who consent to a distinctively cosmopolitan understanding. It is easy to say that cosmopolitanism should emphasize "hybridity, multiplicity, inclusivity and acknowledgement of diverse cultural forms and expression." But if "cosmopolitanism is based on an ethic of inclusiveness, emphasizing communitarianism and the enactment of principles of hospitality to strangers," ${ }^{4}$ the question is "Which strangers do we owe hospitality to? All strangers, or only some of them?" Of course, the modern cosmopolitan would like to say, "All strangers." But ancient cosmopolitans would have said "Some." And modern cosmopolitans seem committed by their arguments to saying "Some" as well as "All."

\section{How Free is One to Be a Cosmopolitan?}

In older forms of cosmopolitanism, one was free to join the higher city, even if one had an obligation to join it. The obligation was not a matter of coercion, but of conviction. Modern cosmopolitanism, by contrast, seems to involve coercion.

Let me be exact about the difference between Stoicism and Christianity. As Hegel said, Stoicism was a very simple and adaptable philosophy, since it involved the imposition of the simplicity of thought on reality so that universality could be found in the universe. ${ }^{55}$ Stoics thought that reason committed us to their point of view, but there was no question that other philosophers-Epicureans, for instance-thought that reason committed us to a different view, while Sceptics argued that reason committed us to no particular view more than any other. One was free, then, to become cosmopolitan, and one did so by joining a community of philosophers who advocated cosmopolitanism. In a sense, then, one was a cosmopolitan as soon as one said one was. In addition, Stoicism was a universal system which existed in a world which took natural inequality for granted. It followed that only an elite could belong to the higher city. Christianity of course introduced a novelty in its claim that all humans in principle could belong to the city, even if all did not in practice belong to it. Christianity also differed from Stoicism for a reason expressed very clearly by John Potter in the early eighteenth century. He observed that others had "conceived the Christian church to resemble a society of philosophers, where many useful and excellent truths are taught." He pointed out that "no man is obliged to come into [such a philosophical society], or to continue in it: and if any man has learned the truths which are there delivered, by any other means, it is all one as if he had lived in the society." A church, on the other hand, unlike a society of philosophers, was "not a mere voluntary society, but one whereof men are obliged to be members." ${ }^{26}$ So there was a shift: the earliest, philosophical, cosmopolitanism was voluntary, even if the philosophers thought that reason compelled us to become cosmopolitan, whereas the later, theological, cosmopolitanism was obligatory, because it was not reason as such but God who compelled us to become cosmopolitan. Nonetheless, we were still free: just as free to live in sin as we had been free to live in ignorance. Even Hobbes saw 
this very clearly, stating in Leviathan that "Faith hath no relation to, nor dependence at all upon Compulsion, or Commandment." 57

In short, there seem to be three abstract possibilities: (1) I belong to the higher city because I want to belong to it; (2) I belong to the higher city because I am obliged to belong to it; and (3) I belong to the higher city because I am compelled by force to belong to it.

Each of these hypothetical claims could be made by modern cosmopolitans. I happen to think that most modern cosmopolitans are torn between the first and second possibilities: some would like to say that we are free to become cosmopolitan and some would like to say that we are obliged to become cosmopolitan. Almost none would say that obligation is not enough and that force is necessary. This is too Hobbesian a position for most cosmopolitans, though there is no reason why a completely committed cosmopolitan could not argue this way.

Nonetheless, modern cosmopolitans are wholly at a loss as to how to frame an argument which can convincingly show us how we could belong to a cosmopolitan order except by force. Classical cosmopolitanism suggests that we decide: we act (and some lack the capacity to act); theological cosmopolitanism suggests that God acts: we react (and some freely choose not to react); but modern cosmopolitanism seems to suggest that no one acts: no one decides, and no one is excluded. The criterion of inclusion is so underspecified and the apparent need to consider ourselves cosmopolitan so imperative (for those who advocate it) that all are included: not because they have made a choice or responded to an obligation-both of which would require a decision on their part-but simply because they have been herded into a community. This requires force. Or fate.

"Fate" is just another word for force. To be fated to do something is to be forced to do it, so we could say fate is force by history. If then we are told "You are cosmopolitan whether you like it or not," this is by fiat, where fiat may be fate (if we are told it has already happened) or force (if we are told it is about to happen). Since, as I have argued, modern cosmopolitans are at least partly monistic because they think that history is on their side, it is no wonder that their arguments involve force. This force is even more reprehensible than the force used by the gods, since the gods at least gave us a choice, whereas humans may not do so.

\section{Conclusion}

In his recent book Human Evolution, Robin Dunbar tells us that humans are unique among all animals for their religion and their ability to tell stories. "What is important about both is that they require us to live in a virtual world, the virtual world of our minds. In both cases, we have to be able to imagine that another world exists that is different to, and separate from, the world we experience on an everyday basis." ${ }^{58}$ Cosmopolitanism, then, seems a fundamentally human possibility. The belief that there is another world in which all humans exist together as equals may have a far longer ancestry than we can know. The belief that the existence of such a world has consequences for our world certainly has a long history. But the belief that this other world is to be identified with the world we do know is a very recent development, and, I think, a highly questionable one.

I have shown in this article that older cosmopolitanisms distinguished a higher and a lower city, in terms of a relation of humans to the gods or God, in terms of a criterion which included some and excluded others, and therefore left one free to belong to the higher city or not. Modern cosmopolitanism is only explicit on the second of these, and does not 
distinguish anything in relation to the gods. But it is consequently ambivalent about whether there is a higher as well as lower city, whether there is a criterion which includes some and excludes others or not, and whether one is free to belong to the higher city or not. At times it seems to involve the belief that one is not free to choose whether one belongs or not. This is because there is no criterion, and all of us belong to one city. All of the ambiguities of modern cosmopolitanism are thus due to this fundamental contradiction.

The contradiction can be stated in short order. Modern cosmopolitans postulate the existence of two cities and also postulate the existence of only one. For a modern cosmopolitan theory to be cosmopolitan it has to postulate that there are two cities. But for a modern cosmopolitan theory to be modern it has to postulate that there is one city. This contradiction is so blatant that it may seem remarkable that there is such a thing as modern cosmopolitanism at all. There is such a thing because modern cosmopolitans treat this contradiction, where they treat it at all, as evidence of a difficulty (to be overcome, or ignored, in some sort of theoretical compromise) rather than as a demonstration of an impossibility. Hume argued that "Nothing can be more absurd than [the] custom of calling a difficulty what pretends to be a demonstration and endeavoring by that means to elude its force and evidence." ${ }^{59}$ David Stove has shown how Kant's philosophy depends on asking the question "How is p possible given q?" instead of the question "Is p possible given q?" 60 Modern cosmopolitan theorists should similarly ask, "Is cosmopolitanism possible given its contradiction?" to which the answer should be "No." But instead they ask the question in Kantian form: "How is cosmopolitanism possible given its apparent contradictions?" to which their answer is "By some form of compromise." Which is then written about ad infinitum in terms of a "layered," "partial," "moderate," or "balanced" cosmopolitanism. To this it is necessary to say that no amount of adjectival cosmopolitanism should conceal its fundamental contradiction. Samuel Scheffler has said that cosmopolitanism at first sight seems either "platitudinous" or "implausible," 61 but I would argue that it is both platitudinous and implausible (though of course, inspiring, admirable and so on) - because it is fundamentally contradictory.

This point was made by Bernard Bosanquet over a century ago when he wrote that the "object of our ethical idea of humanity is not really mankind as a single community." The "idea of humanity" (a "problem") must be distinguished from the "interests of mankind" (a "fact"). They must never be confused with each other. "No such identical experience can be presupposed in all mankind as is necessary to effective membership of a common society and exercise of a general will." ${ }^{2}$ This distinction between humanity and mankind - not the words, but what is meant by the words-is very important. For humanity means the ideal humanity of a unitary order or higher city, whereas mankind means all humans. We may of course characterize mankind-that is, all of us in all the cities of the earth-in terms of something like "sociability"; but this can never be a specification of the idea or ideal of humanity which, by definition, discriminates something which is valued, something higher, from something lower.

Modern cosmopolitanism, lacking reason and faith, or, to be accurate, having a concept of reason which is liberal and tolerant and having a secularized faith which is more or less the same as hope where it is not the same as a belief in progress-this modern cosmopolitanism leaves everything open. But if neither reason nor faith can point us to the higher city, then there is only force. 
This is not an original argument. Thomas Nagel's verdict ten years ago was "Hobbesian in spirit: the path from anarchy to justice must go through injustice." He suggested that cosmopolitanism can only depend on "effective but illegitimate institutions to which the standards of justice apply." ${ }^{63}$ This may be the inevitable conclusion of any attempt to theorize the overcoming of the distinction between two cities to create one city. But Nagel did not go far enough in explaining the problem. Robert Nozick once wrote that "a philosophical argument is an attempt to get someone to believe something, whether he wants to believe it or not." ${ }^{64}$ And, by the same token, I think that philosophical argument indicates that modern cosmopolitanism is contradictory, whether we want to believe it or not.

\section{Acknowledgement}

I am indebted to Aron Telegdi-Csetri and Viorela Ducu for organising a very interesting conference in Bucharest in 2011, and to some of the speakers, especially Garrett Brown, Elena Trubina and the late Gary Banham, for vinous and vigorous conversation. This paper originated in thoughts I had before and after that conference. I have done greater battle with editors over this article than over any other I have written. The etymological root of the word 'debate' is, interestingly, the same as that of the word 'battle': but I found very few journals willing to engage in debate. It was rejected by seven journals, if not summarily, then usually on grounds of incomprehension. I am grateful, therefore, to the editors of The European Legacy for showing some faith in someone who is sceptical about cosmopolitan arguments.

\section{Disclosure statement}

No potential conflict of interest was reported by the author.

\section{Notes}

1. Costas Douzinas, "The Metaphysics of Cosmopolitanism," in After Cosmopolitanism, ed. Rosi Braidotti, Patrick Hanafin, Bolette Blaagaard (London: Routledge, 2013), 57-76.

2. See, for instance, Pippa Norris and Richard Inglehart, eds., Cosmopolitan Communications: Cultural Diversity in a Globalized World (Cambridge: Cambridge University Press, 2009).

3. See Zlatko Skrbis and Ian Woodward, Cosmopolitanism: Uses of the Idea (London: Sage, 2013), $4-5$, for a remarkable list.

4. Catherine McKinnon, "Cosmopolitan Hope," in The Political Philosophy of Cosmopolitanism, ed. Gillian Brock and Harry Brighouse (Cambridge: Cambridge University Press, 2005).

5. Samuel Scheffler, "Conceptions of Cosmopolitanism," in Boundaries and Allegiances: Problems of Justice in Liberal Thought (Oxford: Oxford University Press, 2001), 109.

6. Gerard Delanty, Cosmopolitan Imagination: The Renewal of Critical Social Theory (Cambridge: Cambridge University Press, 2009).

7. Charles Beitz, Political Theory and International Relations, $2 \mathrm{~d}$ ed. (Princeton, NJ: Princeton University Press, 1999), 183.

8. Michael Oakeshott, The Concept of a Philosophical Jurisprudence: Essays and Reviews 1926-51, ed. Luke O’Sullivan (Exeter, UK: Imprint Academic, 2007), 97.

9. See, among others, beginning at the head of the alphabet, Kwame Anthony Appiah, Cosmopolitanism: Ethics in a World of Strangers (London: Allen Lane, 2006), Ulrich Beck, Cosmopolitan Vision, trans. Ciaran Cronin (Cambridge: Polity Press, 2006), Gillian Brock, Global Justice: A Cosmopolitan Account (Oxford: Oxford University Press, 2009), and Garrett Brown, Grounding Cosmopolitanism: From Kant to the Idea of a Cosmopolitan Constitution (Edinburgh: Edinburgh University Press, 2009). 
10. W. E. H. Lecky, History of the Rise and Influence of the Spirit of Rationalism in Europe (London: Longmans, Green and Co., 1865), vol. 2, 107.

11. Brown, Grounding Cosmopolitanism, 29.

12. Beck, Cosmopolitan Vision, 45-46.

13. See, respectively, Beck, Cosmopolitan Vision, Jacques Derrida, On Cosmopolitanism and Forgiveness, trans. Mark Dooley and Michael Hughes (London: Routledge, 2001), and Thomas Pogge, World Poverty and Human Rights: Cosmopolitan Responsibilities and Reforms, $2 \mathrm{~d}$ ed. (Cambridge: Polity Press, 2008).

14. See Derek Heater, World Citizenship and Government: Cosmopolitan Ideas in the History of Western Political Thought (London: Macmillan, 1996), and Jens Bartelson, Visions of World Community (Cambridge: Cambridge University Press, 2009).

15. M. H. Boehm, "Cosmopolitanism," in Encyclopaedia of the Social Sciences, ed. Edwin Seligman (London: Macmillan, 1931), vol. 4, 460-61.

16. The Politics of Aristotle, trans. and intro. Ernest Barker (Oxford: Clarendon Press, 1946), lix-lx.

17. Diogenes Laertius, Lives of Eminent Philosophers, trans. R. D. Hicks (Cambridge, MA: Harvard University Press, 1925), vol. 2, 39.

18. Malcolm Schofield, "Social and Political Thought," in The Cambridge History of Hellenistic Philosophy, ed. Keimpe Algra (Cambridge: Cambridge University Press, 1999), 768.

19. Thomas Hobbes, Leviathan, Or the Matter, Forme and Power of a Common-Wealth Ecclesiastical and Civil (1651), ed. C. B. MacPherson (Harmondsworth, UK: Penguin, 1985), 498.

20. Bartelson, Visions of World Community, 16.

21. Braidotti, Hanafin, Blaagaard, After Cosmopolitanism, 3.

22. See Beck, Cosmopolitan Vision, 19, Delanty, Cosmopolitan Imagination, 5, and David Held, Cosmopolitanism: Ideas and Realities (Cambridge: Polity Press, 2010), 50.

23. Braidotti, Hanafin, Blaagaard, After Cosmopolitanism, 2.

24. See, usefully, Jeremy Waldron "What is Cosmopolitan?" The Journal of Political Philosophy 8 (2000): 227-43.

25. See David Held, "Principles of Cosmopolitan Order," in Brock and Brighouse, The Political Philosophy of Cosmopolitanism, 26, and Derrida, On Cosmopolitanism and Forgiveness.

26. Immanuel Kant, Foundations of the Metaphysics of Morals, trans. Lewis White Beck (New York: Liberal Arts Press, 1959), 51.

27. Katrin Flikshuh, "Kant's Kingdom of Ends: Metaphysical not Political," in Kant's 'Groundwork of the Metaphysics of Morals': A Critical Guide, ed. Jens Timmermans (Cambridge: Cambridge University Press, 2009).

28. Christine Korsgaard, Creating the Kingdom of Ends (Cambridge: Cambridge University Press, 1996).

29. Catherine Lu, "The One and Many Faces of Cosmopolitanism," The Journal of Political Philosophy 8 (2000): 257.

30. Ulrich Beck and Johannes Willms, Conversations with Ulrich Beck (Cambridge: Polity, 2004), 181.

31. Robert Fine, Cosmopolitanism (London: Routledge, 2001).

32. Held, Cosmopolitanism: Ideas and Realities, 14.

33. Ulrich Beck, "The Cosmopolitan Perspective: Sociology in the Second Age of Modernity," in Conceiving Cosmopolitanism: Theory, Context, and Practice, ed. Steven Vertovec and Robin Cohen (Oxford University Press, 2007), 83.

34. Bartelson, Visions of World Community, 3,2.

35. Bartelson, Visions of World Community, 174.

36. Diogenes Laertius, Lives of Eminent Philosophers, 73.

37. Malcolm Schofield, The Stoic Idea of the City (Cambridge: Cambridge University Press, 1991), 93. Emphasis added.

38. Lecky, History of the Rise and Influence of the Spirit of Rationalism in Europe, 204.

39. Carl Schmitt, Political Theology: Four Chapters on the Concept of Sovereignty, trans. George Schwab (Chicago, IL: University of Chicago Press, 2005), 36. 
40. Jonathan Israel, A Revolution of the Mind: Radical Enlightenment and the Intellectuals Origins of Modern Democracy (Princeton, NJ: Princeton University Press, 2002), 11-12.

41. David Boucher, Political Theories of International Relations: From Thucydides to the Present (Oxford: Oxford University Press, 1998).

42. Karl Marx, Selected Writings, ed. David McLellan (Oxford: Oxford University Press, 2000), 71.

43. Cicero, De Re Publica, De Legibus, trans. Clinton Walker Keyes (Cambridge, MA: Harvard University Press, 1928), 321-23.

44. Augustine, The City of God Against the Pagans, ed. R. W. Dyson (Cambridge: Cambridge University Press, 1998), 632.

45. Bartelson, Visions of World Community, 139, 181.

46. For instance Beitz, Political Theory and International Relations, Thomas Pogge, Realizing Rawls (Ithaca, NY: Cornell, 1989), and Brian Barry, Justice as Impartiality (Oxford: Clarendon Press, 1995).

47. See Toni Erskine, Embedded Cosmopolitanism: Duties to Strangers and Enemies in a World of "Dislocated Communities" (Oxford: British Academy, 2008), and David Harvey, Cosmopolitanism and the Geographies of Freedom (New York: Columbia University Press, 2009).

48. See, among many, Held, Cosmopolitanism: Ideas and Realities.

49. Erskine, Embedded Cosmopolitanism, 144.

50. Held, Cosmopolitanism: Ideas and Realities, 16, 80.

51. Held, "Principles of Cosmopolitan Order," 249-52.

52. Held, Cosmopolitanism: Ideas and Realities, 24.

53. Harvey, Cosmopolitanism and the Geographies of Freedom, 77-99, esp. 80, 85, 107, 97, 247.

54. Skrbis and Woodward, Cosmopolitanism: Uses of the Idea, 114.

55. G. W. F. Hegel, Lectures on the History of Philosophy, trans. E. S. Haldane and F. H. Simpson (London: Kegan Paul, Trench, Trubner and Co., 1894), vol. 2, 237.

56. John Potter, A Discourse of Church Government (1707), $7^{\text {th }}$ ed. (London: Thomas Tegg, 1839), 5.

57. Hobbes, Leviathan, 526.

58. Robin Dunbar, Human Evolution (London: Pelican, 2014), 19.

59. David Hume, Treatise of Human Nature, ed. L. A. Selby-Bigge (Oxford: Clarendon Press, 1931), 51.

60. David Stove, "Robert Nozick's War Wounds," in The Plato Cult and Other Follies (Oxford: Blackwell, 1991), 48-49.

61. Scheffler, "Conceptions of Cosmopolitanism," 118.

62. Bernard Bosanquet, The Philosophical Theory of the State (1899) (London: Macmillan, 1925), 305-9.

63. Thomas Nagel, “The Problem of Global Justice," Philosophy and Public Affairs 33 (2005): 147.

64. Robert Nozick, Philosophical Explanations (Oxford: Clarendon Press, 1981), 4. 